\title{
EVE: INFLUENTIAL GLIMPSES FROM HER STORY
}

\author{
Maretha M Jacobs \\ University of South Africa
}

\begin{abstract}
Having inherited Christianity and its institutional manifestations from their male ancestors, whose voices were for many centuries, and are still, inextricably linked to that of God, women only recently started to ask the all important why-questions about the Christian religion, its origin and its effects on their lives. In this article a look is taken at some glimpses from the mostly male story about Eve, by which women's lives were deeply influenced. By detecting the contexts, history, motivations and interests behind aspects of this story, it is exposed for what it is: A male construct or constructs and not "how it really was and is" about Eve and her female descendants.
\end{abstract}

Keywords: Eve, History of Interpretation, Feminist Criticism

\section{Introduction}

Take a narrative of human origins which originated in a patriarchal culture in which a woman plays a prominent role, though she is - supposedly - also the biggest culprit, include this narrative, and character, in the genre Holy Scriptures, situate it at a strategic position within these Scriptures where it becomes not merely $a$, but the story of human origins, and later on especially that of sin, leave - for many centuries - its interpretation mainly to the "other" sex within ever changing contexts, though predominantly those unfriendly to women, make it an essential building block of a belief system. And you are left with the kind of interpretation history and impact of the story of Eve, which has for a long time been the dominant one.

In hindsight this is what can be said, in a hopefully not too simplistic and one-sided nutshell, about what happened to the "second" (though chronologically the first) of the two creation stories in Genesis, its female character and her interpretations. Of course this is not the whole story. In genres such as art, literature, films et cetera, less rigid and more imaginative interpretations of this narrative were sometimes made than the mostly literal ones that became part and parcel especially of Christians' make-up. Though many of these interpretations are influenced by the traditional ones (cf. Norris 1999).

Of course Eve was not always regarded to be the sole scapegoat. In Rom 5:12-21 Paul's emphasis is on Adam's disobedience and its implications for humanity. The reason why he focused on Adam was probably not that he was more sympathetic towards women than his successors, but because men were in his time regarded as the moral and social leaders. He, moreover, needed a male figure as counterpart for Christ. The huge difference between Adam and Eve's "sin" is that Adam's sin did not result in subordination and silence for his male descendants. On the contrary, despite their status as sinners his male descendants were, according to the Christian religion, those chosen to rule and speak on behalf of God. And would thus become the sole creators of the Christian symbol system. The rise of critical biblical scholarship in the eighteenth century did make a difference to the traditional interpretation of this narrative, made more informed and thus fairer interpretations possible. 
These interpretations only recently started to exert some influence. Here our interest is mainly in the most influential ones, those which contributed to the fact that, in addition to being a narrative of human origins, the Garden Story became the beginning of and incentive to a long and often denigrating narrative about the "second" sex, her sin, subordination and silence.

If the opening paragraph could be regarded as in some way a valid summary of Eve's fate and some of the factors contributing to it, in what follows selected parts of it will be told in greater detail. The story I will put together here, will focus on the what of Eve's story as interrelated with the who and why of it, that is, the often veiled parts of the story. In the end it may turn out that there is, or was, not so much about Eve than about her male interpreters.

Eve is of interest to us both for her own sake and for ours. Her story is not merely that of a three millennia old story character which we attempt to uncover merely for interest's sake. Though by contemporary insights only a character in a story (myth), precisely as this character in this story Eve crossed continents, became interwoven with many "things," and influenced the lives of countless women up to the present. Through her long, not yet terminated "life," through the generalisation of her character to include her female descendants, Eve has become "[e]verywoman, the prototypical woman, all of her sex who are yet to come" (Phillips 1984, xiii; Schüngel-Straumann 1993, 52). Later generations of women within the Christian tradition and cultures influenced by it would not only be typified on account of her supposed "nature." They would have to suffer for her sin. Apart from being part of Jews' and Christians' narrative of origins, Eve's story is at the heart of the concept of woman in Western civilisation (Phillips 1984, xiii).

Though the main emphasis will be on Eve, her history of interpretation and the impact of these, there are various by-products which come with the remembering of (parts of) a story which has been told for so many centuries. These assist in providing the contexts for what happened to her and why. Through her long "life," Eve has been looked at from different angles. Her story has become a narrative of shifting interpretative contexts, and of varying interests. It sheds light on ways of reading, especially how Holy Scriptures are mostly read and function: Selective, without attention to context, often with veiled agendas and always authoritatively. It also sheds light on how important narratives of origin are to people, what they do with and to these narratives in order to answer their own questions and meet their own needs (Pagels 1988, xix, xx).

While Eve's story has in the course of time become diverse in nature, in one respect it is not really such a diverse one. There is a thread which runs through her narrative and at least ninety per cent of its interpretations. Having, according to the Genesis narrative, been made from man, she has since then mainly been made by man, that is, she has been looked at with male interpretative eyes ever since. Eve's story has therefore mostly been that of male estimation, male honour, male anxiety, always with a strong dose of male authority added to it. In the words of Norris $(1999,403)$ : “[I]n Eve's many faces we have a unique record of the male imagination at work, wrestling with the female other." Since the male voice has in the field of religion and theology for such a long time been the only one, and is still the dominant one, this fact has been veiled: What they said about her has for a long time been regarded as "how it really is" about Eve.

But why do we want to remember a narrative which is for a great part, from a woman's point of view, such a gloomy one? Hasn't it by this time to a large extent become dated? We have not yet escaped the impact of this story, although, as a result of the subconscious nature of the effect of religious traditions, this is often not realised. Ignoring the past does 
not obliterate its influence. It is therefore necessary to bring down to earth what often still hovers in the air, to bring to the surface what functions underneath, to make Eve's interpreters and their contexts and interests explicit. Now that we are able to recognise previous influential interpretations for what they are, we want to see for ourselves. Now that more information is available about the nature of the narrative and its origin, we want to have another look. Perhaps also because remembering has become less painful now that women are no longer "the mute and passive objects of male thought and action" (Sawyer 1996, 2). Having determined her origin and the evolvement of her character, it is easier to leave her behind (Norris 1999, 403).

How does one decide on the components or glimpses for one's story in order to make it a fair and credible one, while at the same time keeping in mind that in this case too much balance can distort its often one-sided effect/influence? Among Jews, among whom Eve originated, she played and plays a less important role than among Christians; Eve's story and its interpretations do not form an indispensable part of their faith (cf. Barr 1988, 68). It was more or less between 200 B.C.E. and 400-500 C.E. that Eve experienced a flourishing period in terms of attention received, that her "nature" was established, that she landed in the "sin-bin" for many centuries, that her story gained greater momentum by its incorporation into the Christian faith. It is mainly from this period that the few glimpses on which I will briefly focus are taken. If these represent only one trajectory within a more comprehensive story, this has been, in my view, a very influential one.

\section{Ben Sira: Eve as Source of Evil and: Women through the Lens of Male Honour}

It is well known that, unlike other important biblical stories or motives, there are, apart from Gen 2-3, no other references to the story of Adam and Eve in the Hebrew Bible. Nowhere in the Hebrew Bible do we, for example, get the idea that woman is more to blame for the origin of evil than is man (Barr 1988, 70). Only during the intertestamental era, beginning with the work of Ben Sira does Eve reappear on the scene. Not an explicit comeback, one has to admit - for she is not mentioned by name. However, since "woman" is here used in the singular, most commentators think that this has to be understood as a reference to Eve, the "first woman" (Sir 25:24). So, after many centuries, "Eve-talk" commences, not as "life-talk" (Gen 3:20), but as talk on evil. For it was during this time that the question of the origin of evil and of suffering became important. Eve's rise to the limelight coincided with the rise of this question.

In the Wisdom of Ben Sira (180 B.C.E.) a lot of attention is paid to women, a feature characteristic of the Hebrew wisdom tradition, the genre to which his work belongs. In Proverbs true wisdom is poetically depicted as a good woman (9:1-16). She is then contrasted with the adulterous woman (Sawyer 1996, 131). Although it was characteristic of his society and age to write a great deal more about the evil woman or wife than about the good one (Di Lella 1987, 347), nowhere does one encounter the kind of attack on women that one finds in the Wisdom of Ben Sira, not only against traditional evil women, but also against one's wife and daughters (Camp 1991, 5). In one of his fiercest attacks on women we hear that "no venom (is) greater than that of a woman," and that "there is scarce any evil like that of a woman" (Sir 25:15, 19). This is then followed (Sir 25:24) by the implicit reference to Eve ("In a woman was sin's beginning, on her account we all die"), which serves as justification for his views. The very existence of $\sin$ in the world is here attributed to the action of one woman, which had fatal repercussions for all subsequent humanity (Sawyer 1996, 124). 
Although Ben Sira's view was probably only one among others and not representative of the wide spectrum of Jewish belief and practice during the period (Sawyer 1996, 135), it was intended to be passed on. According to Di Lella $(1987,347)$ the unflattering observations about women made in this passage should neither be explained away nor exaggerated. They are simply "accurate reflections of the kind of training for life the young Jewish male received in the early second century B.C.E." Apart from the problem, for women, of passing on a biased view as "how it really is" about women, one could ask what kind of society this sort of teaching would create.

In accounting for his utterances scholars point to the influence of Hellenistic and in particular Aristotelian thought on his work and other sources of the time, such as Philo of Alexandria and Josephus (Barr 1988, 70; Sawyer 1996, 136). In all these sources there is a tendency to portray women not only as the second sex, but as the "other" gender which manifests evil in the world, who "ensnares men, dragging them down to ruin and despair" (Sawyer 1996, 130). By this time the idea existed that women were a sort of natural source of evil (Barr 1988, 71). Related to this conviction was the gaining ground of an essentialist understanding of gender. To trick and seduce was regarded as something "natural" to women (Sawyer 1996, 136). This would later become an important emphasis in the interpretation of Gen 2-3 in general and Eve-talk in particular.

Apart from Hellenistic influence on his work, it is possible to look at Ben Sira's views from yet another perspective. This could result in an even more specific idea about the context of his views. In a carefully argued article Camp (1991) shows how the views about women expressed here are related to Ben Sira's concern for honour, for having a good name, thus for avoiding shame. As a child of his time and of his Mediterranean context, the avoidance of shame was of utmost importance to him. To a situation where values clashed intensely and where status and security were fragile, leading to a lot of anxiety, the natural response was to exert control where he could, that is, in his own household. This also comes to the fore in what he has to say about daughters and good wives (Barr 1988; Camp 1991). His concern is clearly not for the daughter's happiness, but for the father's loss of sleep, and even more important, his loss of honour. Women are in the centre of attention in so far as they serve or endanger the interests of men. In Ben Sira the "good wife" is an evaluative term defined from the male perspective; she is the one who meets the needs and interests of a man. Even her beauty, though desired and sought after, is potentially very dangerous (Milne 1999, 276, 279).

For our purpose Ben Sira's views about women are important in so far as these kind of ideas were in the air when, what would become, the much more influential New Testament writings were written. Though perhaps indirectly, his view on Eve and her descendants would influence the direction in which her story would develop.

\section{The Apocryphal Life of Adam and Eve}

If Eve is only implicitly, though forcefully, present in Ben Sira and his portrayal of women, in other writings from the period or shortly afterwards, she is much more in the centre of attention. One of these writings is The Life of Adam and Eve, a writing (or writings, since there exist different versions of it in different languages) which lately received a lot of attention (Anderson 2001; De Jonge and Tromp 1997). Detailed attention cannot be paid here to the different versions of this book, which differ on some points, and about which dating, provenance and even main emphases there are differences of opinion. The different versions attest to its popularity and influence. The Greek Life of Adam and Eve (GLAE), in 
the past often incorrectly referred to as the Apocalypse of Moses probably goes back to the first or second century C.E.

The Greek Life of Adam and Eve is a free retelling of Gen 3. It narrates a number of episodes in the life of Adam and Eve after their expulsion from Paradise. When Adam falls ill, he and Eve reflect in two flashbacks on the reason for his illness, that is, the events in the Garden of Eden. Eve's version of the events is the more comprehensive one (chs. 1530). Not all scholars agree on who is, according to the text, the most to blame for the entry of illness and death into the world. Though this is certainly not the writing's only concern and according to some not even its main theme (De Jonge and Tromp 1997, 45-58), attempts to soften the writing's blame of Eve may be more in line with current sentiments than with those of the text itself. It seems clear that most of the blame for sin, illness and death is indeed here put on Eve. It is repeatedly asserted that sin has entered the world through a woman (GLAE 9:2;11;14:2;21:2, 6; 24:1;29:3;32:1-2). In fact, she is here not merely accused by Adam; in the writing she blames herself for eating the fruit and for tempting Adam (GLAE 32:2: "All sin in creation has come about through me"), and is thus responsible for the entrance of death into the world. To grasp the full force of this, one has to keep in mind that behind the first person utterances there almost certainly lurks a male author. What we have here is therefore not an admission of guilt by a female, but a (veiled) accusation by a male. In this writing not only Eve comes off worse than in the Genesis narrative. The somewhat ambiguous snake-figure of Genesis has now become more clearly delineated: He is now the accomplice of Satan. The scapegoating of Eve may relate to the misogyny characteristic of writings of the time on female behaviour referred to above. It may also be related to the perfectionist idea of Adam that was becoming an important theme in the Eden tradition (Norris 1999, 98).

\section{Timothy 2:8-15: Deception, Subordination and Silence}

"I do not permit a woman to teach or to have authority over a man; she must be silent. For Adam was formed first, then Eve. And Adam was not the one deceived; it was the woman who was deceived and became a sinner." (1 Tim 2:12-14). This passage from a short epistle, probably not even written by Christianity's great authority, became one of the most influential in the New Testament, the foundation text in Christian theology about women and their role and status in the church, the corner-stone of later Christian teaching about women (Norris 1999, 172; Sawyer 1996, 153). A text which is so (deceptively?) clear that there was from early on no doubt about its meaning. It did not even need interpretation; it could merely be quoted, as for example the writings of the Church Fathers abundantly show. And, nearly ever afterwards, up to very recently, came down upon Christian women with the force of dogma. Thus it became a crucial factor in determining the official face of the Christian churches and societies influenced by it.

Various factors contributed to this text's interpretation and influence. There was the fertile patriarchal ground in which this text originated and within which it would be interpreted for nearly two thousand years. Perhaps even more crucial is that the Pastor's voice, for a long time regarded to be that of Paul, was from early on blended effortlessly with that of God.

For centuries of male interpretation this text was accepted without protest by those unaffected by it. Some male interpreters even thought the restrictions to be beneficial to women. According to Schlatter the injunctions were actually a blessing from God, who allows women to be silent, thereby freeing them from the tasks of instructing and guiding 
the church (cf. Bassler 1988, 44). As recently as 1995, having paid extensive attention to this passage and its history of interpretation, a number of scholars in the Evangelical tradition still decide to retain the age-old policy of the Christian churches that women should be silenced in the churches (Köstenberger, Schreiner and Baldwin 1995). In a recent publication of a minister of the Dutch Reformed church who wrote a doctoral thesis on prayer, we are exhorted to pray that women should be submissive to their husbands and that men should use their God given authority correctly and not relinquish it to their wives (Mostert 2003, 126-128). So strong is the momentum of centuries of traditional interpretations of this text, and its consequences, that even in churches which no longer adhere to these, it makes little difference. The reference to the Protestant churches as "a sombre-suited masculine world ... altogether too much like a gentleman's club" (Warner, quoted in Hampson 2002, 204) still does not sound inapt even in our time and would at least apply to some of the church's current manifestations.

But it is time to return to Eve. We want to know what the Pastor did with and to her and why. How did he apply the story of Adam and Eve to his own situation?

The context in which the injunction to silence and its motivation by means of the Genesis narrative should be understood will not be dealt with in detail (cf. Jacobs 2002). Only those aspects of it relevant to the story of Eve will receive brief attention.

Apart from the broader context of 1 Timothy, a world in which the public sector was regarded as the domain of men, while women were mainly restricted to the private sphere, it seems as if the Pastor had to deal with a specific "threat" to his church from some religious opponents. One aspect of their teaching was probably that they offered freedom from the oppressive patriarchal structure that characterised the Greco-Roman world and was increasingly characterising the church. One access route to this freedom was to embrace a celibate lifestyle. Women were probably attracted to this since it provided them with a different option than that of submissiveness to their husbands and having children. It is possible that they even acted as teachers of such a message; hence the Pastor's strong reaction against women as teachers in 1 Tim 2:8-15 (Bassler 1988, 46, 47).

In this context of prohibition we find the reference to Genesis (1 Tim 2:13-14): "For Adam was formed first, then Eve. And Adam was not the one to be deceived; it was the woman who was deceived and became a sinner." Formed first - not deceived. Made second - deceived. A massive contrast indeed. This motivation was, like the injunction to silence in which it is embedded, deeply influenced by views of the time. In biblical times it was assumed that the first-born had higher status than the younger children and therefore authority over them. By referring to the order of creation the Pastor probably wanted to say that women who teach and therefore exercise authority over men go against the order established by God. More puzzling is the reference to the deception of Eve, while Adam is absolved from this. The author's use of Genesis could relate to a literal reading of Genesis, where Eve's transgression is referred to as "deception" by the snake (Gen 3:13). Bassler (1988) thinks that the term "deception" was probably taken up here because it cohered with the Pastor's own situation. More than once in the letter the "heretics" are called deceivers (1 Tim 4:1; 2 Tim 3:13; Titus 1:10). By being attracted to their teaching women were in danger of being deceived by it. The idea of deception, which is in Genesis used in connection with Eve's listening to the serpent, provides the primal connection with the Genesis text. This would imply that the Pastor's context, and therefore practical experience, served as lens for the reading of Gen 3, and coloured it (Bassler 1988, 52).

This "contextual exegesis" of the Genesis story played no part in the way 1 Timothy was passed on. At the time, as for centuries to come, there were no extenuating 
circumstances for Eve. Taken at face value, as was mostly done, this text was from early on regarded as "how it really is" about Eve and her descendants. It extended the gap between man and woman and woman and God. As God's appointed spokesperson, Adam's male descendant is endowed with the authority to enjoin silence on Eve's female ones. The Pastor's view on Eve would become a confirmation of the already existing view of Eve, in some quarters, as the main culprit for the entrance of sin into the world. By linking "sin," in the case of Eve and her descendants, to "silence," men were made the sole legitimate proclaimers of the "Word of God."

\section{The Church Fathers: The Woes Continue - and Increase}

During the first Christian centuries Eve grew in stature, if the even more attention she now received could be regarded as pointing in this direction. During this time we again encounter her as part of a more comprehensive story; her fate has become interrelated with and determined by pertinent issues of the time, such as marriage and asceticism (Clark $1983,17,18)$. The tone of the discussions about women is often set by orthodox-heretic rhetoric. In fact, having early on been identified as one of the crucial issues that needed attention, the matter of women and their position in the Christian churches was settled more or less during the same time as other crucial issues. With the same rigidity with which the Church Fathers formulated the two, perfect natures of Jesus of Nazareth, they talked about the single, sinful nature of Eve and especially about the implications of this for the place of women in the Christian churches. No wonder that it took women such a long time to free themselves from this "dogmatic" position. No wonder that there is still little place and space in the Christian churches for women who do not adhere to the male-made dogmas.

By the time Gen 2-3 reached the Church Fathers, it was already mediated by Paul, and carried his authoritative stamp of interpretation, or so they thought, especially by means of 1 Timothy. This is clear from the many references to this passage in their writings and their taking for granted of its validity and normativity. By this time they could quote both the Old and the New Testament to substantiate their views (Clark 1983, 43-44). The Church Fathers' views often merely entailed the confirmation, in more embroidered form, of what was by that time more or less established as the "truth" about Eve in Genesis and the New Testament. Even though the female reader is at this stage in Eve's story equipped with a substantial dose of suspicion, much of what the Church Fathers wrote about her is still hard to swallow.

The Church Fathers' views on women, which cover more than two centuries, were influenced by their reading of the Scriptures, their own contexts, their questions, their experiences. With regard to women they used the Bible selectively: They often focused on verses that provided a rationale for restricting women (Clark 1983, 16). The Scriptures were, besides, mostly read literally, sometimes mixed with a substantial portion of speculation, sometimes merely quoted. Despite some differences between them a number of tendencies can be pointed out in their views of Eve. They all agreed that Gen 2-3 is about sin and regarded Eve to be (at least partly, if not mainly), responsible for the origin of this $\sin$ (Clark 1983, 27). This was basic to their view of her. With this went the view of some that the blame for the first sin was passed on to all other women. One of the earliest and most forceful expressions of this view is the well-known accusation of Tertullian in his $\mathrm{On}$ the Dress of Woman, where he calls the "dear sisters" (!) whom he addresses "the devil's gateway," on account of whose punishment, that is death, even the Son of God had to die (Clark 1983, 39). 
The Church Fathers emphasised that Eve's subordination was the result of, had to do with, sin. Surprising, for a contemporary reader, is the amount of insight they thought to have had into the mind of God. According to Ambrose, by means of the words "your inclination shall be for your husband and he shall rule over you" God said in effect to Eve: "I made you equal in honor. You did not use your authority well, so consign yourself to a state of subordination" (Clark 1983, 43).

In contrast to this John Chrysostom thought that woman's subordinate status was not simply a result of the fall; she was inferior at the moment of her creation, though she was subjected to man chiefly because of her role in the first sin. In his view on women regarding their "essentialist nature" and their rigidly defined "job description" another factor played a crucial role, that of the clear distinction of life into two spheres, the public and the private sphere, characteristic of the then world: "Indeed, this is a work of God's love and wisdom, that he who is skilled at the greater things is downright inept and useless in the performance of the less important ones, so that the woman's service is necessary. For if the man were adapted to undertake both sorts of activities, the female sex could easily be despised. Conversely, if the more important, most beneficial concerns were turned over to the woman, she would go quite mad" (Clark 1983, 37). And: "God maintained the order of each sex by dividing the business of human life into two parts and assigned the more necessary and beneficial aspects to the man and the less important, inferior matters to the woman" (Clark 1983, 37).

This mentality was more or less canonised and would reign in the Christian churches for many centuries. While the male concept of woman would play an important role in the Christian religion, real, actual women were mostly nowhere to be seen (Hampson 2002, $169,170)$.

How did the Church Fathers make sense of the creation of man and woman? Why is woman "added" to man? How should the relation between them be viewed? In which respect was Eve a helper for Adam? Augustine recognised that God created human beings as man and woman, thus as social beings. There is, however, an order in Genesis, according to which one has to reign and the other has to be obedient. In his view the sole need for woman is her part in procreation; a man could better have fulfilled the other functions such as company and conversation (Clark 1983, 28, 29). Though, according to Ambrose, woman's role in procreation is something very significant, she is still a helper of less importance (Clark 1983, 32, 33).

Perhaps no interpretation of the Genesis narrative has been as influential as that of Augustine on original sin. The complex detail of this view, or doctrine, need not be discussed here. Significant is that at this stage the already formidable accumulation of words starting with an "s" associated with Gen 2-3 and its history of interpretation (snake, Satan, sin, subordination, silence) is joined by yet another one - sex. Although the link between sin and sex predates Augustine's views, in the Western tradition he was largely responsible for the coupling of sexuality with sin (Hampson 2002, 188). According to Augustine sexual desire entered into human experience as punishment for sin (Pagels 1988, xxvii). Since Adam and Eve's disobedience sin is sexually transmitted. For Eve original sin implied severe punishment: It reversed what would have been painless childbearing into painful contractions and marriage free from oppression into oppression by her husband (Pagels 1988, 133). Since Augustine the creation narrative of Gen 2-3 became almost identical with original sin and an indispensable building block of the Christian belief system. 


\section{The Protestant Reformation}

The Protestant Reformation, revolutionary in so many respects that it is sometimes used as the starting-point for the history of the past five hundred years (Barzun 2000), in the end did not substantially change previous views of Eve and her descendants. Initially there were some hopeful signs. According to Martin Luther prior to the fall Eve was the equal of Adam, in no respect inferior to him (Phillips 1984, 99). Calvin thought that she was created in the image of God, "though in the second degree," whatever that means (Phillips 1984, 99). The Reformers rejected troublesome aspects of Eve's story such as her greater culpability and the view of the primal sin as pride (Phillips 1984, 9, 100). Eve was, however, not released from her prescribed role, which was quite different from that of Adam: For, according to Luther, "just as the snail carries its household with it, so the wife should stay at home and look after the affairs of the household" (Phillips 1984, 105). When reading Luther's statement that "as the sun is more excellent than the moon, so the woman, although she was a most beautiful work of God, was nonetheless not the equal of the male in glory and prestige," one starts to question his idea of equality (Phillips 1984, 104). His commentary on 1 Tim 2:8-15 makes one realise that, despite the Reformers' emphasis on grace, Eve's story has, with them, not really moved beyond that of Crime and Punishment. According to Luther the subjection of woman and domination of men have not been taken away. The penalty remains, although salvation is possible by bearing children with pain and rearing them (Fontaine 1997, 89).

\section{Back to Genesis - and its Eve}

It is a sobering experience to go back to Genesis - where it all started - and listen to what contemporary Old Testament scholars have to say about the nature and meaning of this over commentated and overused, mostly misused, text. It is as if a drawn-out gossip story, in which one self has been implicated, is finally coming to an end.

Of course one should not expect unanimity on such a complex text, and one on which so many interpretations have been imposed. Even Old Testament scholars do not always escape from the influence of previous interpretations nowadays regarded by many to be problematic. In his commentary on Genesis, Von Rad, for example, still refers to Eve as "temptress" (Higgins 1976, 639). The aim here is to look at the Genesis narrative from the perspective of two matters which played a crucial role in its interpretation history and impact: Its close association with sin and the origin thereof, and its reading in a literal way, as a historical narrative.

In dealing with Gen 2-3 Barr $(1988,62)$ points out that the term "sin," which has played such a crucial role in the interpretation of this narrative, does not appear here. Though disobedience is at stake, it is doubtful whether this narrative can be regarded as a cataclysmic "fall" which totally alters the status of humankind in relation to God, even the nature of the universe, as Augustine thought (Barr 1988, 62; Bechtel 1993, 82). There is, according to him, moreover no sign in the narrative itself that the motivation for Eve's act was to "be as God"; that the primal sin consisted in pride, in the longing to be like God, as is often thought. Being like God in the ability to distinguish between good and evil, is merely the snake's explanation of why God had forbidden the fruit of this tree. "It was the quality of the tree that attracted her: It was good for food, delightful to the eyes to look upon... At the most the woman was attracted by the food value, the pleasant appearance, and the educative prospects of the fruit" (Barr 1988, 65). Barr $(1988,67)$ points to two other factors against this narrative as the account of the origin of evil: First, the conception 
of a gradual evolution and building up of evil in Genesis, of which Adam and Eve is part, but not the only, not even the central point. Second, the fact that nowhere in the Hebrew Bible the disobedience of Adam and Eve is cited as explanation for the origin of evil in the world.

Related to the clearance of some traditional understandings is the question of the genre to which the Genesis narrative belongs. This is clearly not history, as has been taken for granted for many centuries, but myth. A myth is "the response to a question, the solution to a problem; it is always an explanation" (Bottero 2000, 172). It is the bearer of an interpretation of the world (Bottéro 2000, 173). This implies that it arises from an already experienced reality, and does not precede it. To be concrete: Subordination and birth-pangs, referred to in Gen 3, existed before an attempt to explain them. This is not how it happened, but how people centuries ago tried to understand and explain their own reality and experiences. The fact that it was their, not the explanation, changes the whole matter. In the case of a myth the emphasis is, moreover, not so much on the detail, which has played such an important role in the history of interpretation, as on the idea of which the myth is the vehicle. Bottéro $(2000,174)$ regards the point of the Genesis narrative or myth to be: "If people are what they are, inclined toward evil and burdened with troubles, it is all through their own fault." Viewed in this way, little of what made this myth so influential is to be found in the narrative itself.

It was, of course, not the Eve of modern biblical scholarship, but the misinterpreted Eve, who played the significant role in the drama of history and who is important for an understanding of Western religion and culture (Phillips 1984, xiv). The "fall into sin" is still regarded as an essential building block of the Christian faith, while "Eve" still has little say in many Christian churches.

\section{The Second Eve}

If (some of) modern biblical scholarship has "redeemed" Eve by problematising the assumptions behind the way she has been interpreted in the past, some interpreters, usually male ones, point to another kind of "redemption" of Eve which goes much further back: The correlation which had from early on been made between Eve and her counterpart Mary, who are often contrasted in terms of disobedience/obedience. Some even think that the significance of Eve can only be grasped if one understands how she points towards Mary (Anderson 2001, 84). Implementing a typical Christian way of reasoning and interpretation, Anderson $(2001,85)$ argues that first things can only be understood by virtue of last things. This implies that it may be a mistake to interpret the "first woman" without recourse to the "last woman."

These views, which cannot be dealt with here in detail, elicit several questions. What, for example, about the in-between, when "Eve" and her sinful descendants were still on their own, without a "saving counterpart," when neither the "real Mary" nor the "Second Eve," created by the male Christian imagination, existed? The problems are even graver if Mary as "Second Eve" is seen as a solution for the predicament of Eve's contemporary descendants. For it is woman as mother, and not woman as independent agent, who is idealised in the figure of Mary. In this regard Cupitt strikingly remarks that one never sees Mary portrayed with her mouth open, laughing or speaking, let alone as a sexual being showing affection for her husband, a subject in her own right. Powerful she is, but only in relation to her (boy) child (cf. Cupitt, quoted in Hampson 2002, 174, 175). To this should be added that the ideal of virgin motherhood is unattainable for normal women. Norris 
$(1999,232)$ calls it the great irony of Christianity that, on the one hand, it laid enormous emphasis on female salvation through motherhood, while, at the same time it venerates a virgin mother as its supreme image of maternity. "The effect of these powerful ideas about sex-free maternity was to separate Mary from the common lot of womankind and from normative processes of sexual intercourse, childbirth and even death" (Norris 1999, 233).

\section{Eve Tells Her Own Story}

Having paid attention to the chronicle of some male interpretations of Eve, it has become more than clear that Eve's story has mostly (except for the work of some recent biblical scholars) been read against rather than for women. What remains to be done is to pay attention to a few interpretations of Eve's story by women. What happens, in their hands, to this story? Since Eve started to speak for herself, an immense body of diverse and scholarly sophisticated material has been produced, especially during the past three decades. What I would like to do here, is first to point to a few of those early voices who were not yet part of a concerted effort, who could not rely on the insights of modern biblical scholarship, but who can in a way still set the tone for our work in different contexts. Brief attention will then be paid to the kind of things feminist biblical scholars addressed and still address.

If Eve's story got going in the context of male talk on evil, what difference did it make when women started to interpret? If the male story about Eve was mainly about sin, submission, silence, and inferiority, if it was mostly a gloomy one, can some changes be detected, not only in content but in mood? Her stories, of course, presupposed his stories, and therefore had to respond to these; they did not merely comment on the Genesis narrative. What comes clearly to the fore, in this case, is that who reads and interprets matters immensely, that at least in this case it mattered immensely. Gaps are filled in differently. The other side is spotted and emphasised. It should also be kept in mind that, unlike their male counterparts, women did not receive support for their understanding and interpretation of the Genesis narrative elsewhere in the Bible: They had to rely on their own intellect, their common sense and their imagination. Although, judged by the standards of modern biblical scholarship, many of these early interpretations would today not be regarded as responsible exegesis, there are some positives. In reading some of these a lightness and down-to-earthiness can be detected. At least these interpretations are no less legitimate than those which were imposed on the Genesis narrative by males and which dominated the interpretative scene for most of the Common Era.

In these early writings all the most important themes in the history of Eve's interpretation crop up and are responded to. One of those dealt with, is that of male superiority/ female inferiority. In her meditations on Adam and Eve, Hildegard von Bingen (10981179) stressed the cooperation between man and woman, instead of the submission of woman to man (Norris 1999, 153, 154). Christine de Pizan (1365-1430) similarly emphasised that the way of Eve's creation suggests that "she should be at his side as a companion and not at his feet like a slave" (Norris 1999, 355). Eve was formed equally with Adam in the image of God (Norris 1999, 355). She interpreted the "image of God" as referring to the soul: "God created this soul and put completely equal souls, one as good and noble as the other, into the female and male bodies" (Norris 1999, 356). In some cases the superiority of Eve is even pointed out, both with regard to her body, and her function. Woman's body is regarded as purer because it is made of man's flesh and not of filthy clay: Her body is also the means "whereby the world increases" (Norris 1999, 357). According to Hale (1788-1879) Eve was the spiritual leader, the most difficult to be won, and the serpent knew if he could gain her the result was sure (Norris 1999, 361). The woman decided to eat 
because of her "higher faculties of mind" and "the desire for knowledge and wisdom" while the man had no higher motives than gratifying his "sensuous inclinations" (Norris 1999, 361). Adam first/then Eve is now interpreted differently: "Woman was the crown of creation, the last, and must therefore have been the best in those qualities which raise human nature above animal life" (Norris 1999, 361). Over against the woman as the "helper" destined for the inferior tasks, emphasised by some of the Church Fathers, men are now blamed for laying the whole burden of domestic affairs on their wives. The words of Speght, by the time of writing this in 1616 not even twenty, are worth quoting: "Just as the male pigeon is happy to take his turn at egg-sitting, or among smaller birds the cock is a willing partner in constructing the nest, so much the more should man and woman "who are reasonable creatures be helpers to each other in all things lawful" (Norris 1999, 358). This vision is only in our time starting to materialise.

By the time The Woman's Bible (1895), the first systematic attempt by women to comment on and critique the biblical narratives that have for centuries been used against them, was initiated by Elizabeth Cady Stanton, the context for the interpretation of Gen 2-3 had changed. The insights of biblical scholarship as well as the Darwinian theory of evolution could be used in its interpretation, although feminist biblical scholars were reluctant to take part in the project (Christ and Plaskow 1979, 19). In her discussion of Eve's encounter with the serpent, Stanton wrote that, whatever the nature of the story, historical fact or allegory, the woman's behaviour shows courage, dignity and lofty ambition. "The serpent recognised her 'higher character' and instead of tempting her with jewels, frocks, luxuries and so on, he roused in the woman that intense thirst for knowledge, that the simple pleasures of picking flowers and talking with Adam did not satisfy" (cf. Stanton, quoted in Norris 1999, 362). According to her the supposed curse of maternity and childbearing could be easily transformed into a blessing by the observance of physical and psychical laws (Norris 1999, 363).

Since the seventies of the twentieth century feminist biblical scholars paid detailed attention to this passage and its female character. As a result of the long and one-sided effect of this story, their work entailed (and still entails) both questioning, from a suspicious angle, of previous interpretations and reinterpretations of it. Whereas some think that not the text itself, but centuries of male misinterpretation, was and is the source of the problem for women and that a more woman-friendly interpretation of it is possible (Trible 1979), others are more sceptical about the matter and emphasise the deeply patriarchal nature of Gen 2-3 (Milne 1999). Probably most feminist biblical scholars would agree that, while this is not a "feminist story," it is at least less blameful towards Eve than the male interpretations which dominated the scene until recently. Which is, of course, perfectly in line with the way in which a gossip story usually functions.

By moving away from a literal reading to a focus on the structure of and the symbols within the narrative, some feminist biblical scholars point to other ways of understanding Gen 2-3 than those arrived at by looking at the story almost exclusively through "singlasses" (Bechtel 1993; Van Wolde 1989).

\section{Conclusion}

"Eve's stunted story is useful as an example of how narrative can catch us out, bind us down, trap us into destinies that we may find desperately uncomfortable," Norris (1999, 403) writes in the afterword of her book The Story of Eve. The discussion of some glimpses from Eve's story provides us with a number of reasons for its aftermath. Not only was her 
story, where it counted most, retold and propagated uncritically, because it was mostly interpreted from the side of the privileged male insider. Even more crucial is that it functioned with God's stamp on it, thus veiling its real origin and making it into a one-andonly story to the exclusion of all others. Understanding where Eve came from and how her character evolved is one way of leaving her behind (Norris 1999, 403). It may, moreover, be the starting-point for many different and diverse woman-stories, which have, in fact, already begun.

\section{BIBLIOGRAPHY}

Anderson, GA 2001. The Genesis of Perfection: Adam and Eve in Jewish and Christian Imagination. Louisville: Westminster John Knox Press.

Barr, J 1988. The Authority of Scripture: The Book of Genesis and the Origin of Evil in Jewish and Christian Tradition. Pages 59-75 in Christian Authority: Essays in Honour of Henry Chadwick. Edited by GR Evans. Oxford: Clarendon Press.

Barzun, J 2000. From Dawn to Decadence: 500 Years of Western Cultural Life: 1500 to the Present. London: HarperCollins.

Bassler, J 1988. Adam, Eve and the Pastor: The Use of Genesis 2-3 in the Pastoral Epistles. Pages 43-65 in Genesis 1-3 in the History of Exegesis: Intrigue in the Garden. Edited by GA Robbins. Queenston: Edwin Mellen.

Bechtel, LM 1993. Rethinking the Interpretation of Genesis 2.4b-3.24. Pages 77-117 in $A$ Feminist Companion to Genesis. Edited by A Brenner. Sheffield: Sheffield Academic Press.

Bottéro, J 2000. The Birth of God: The Bible and the Historian. Pennsylvania: The Pennsylvania State University Press.

Camp, C. 1991. Understanding a Patriarchy: Women in Second Century Jerusalem through the Eyes of Ben Sira. Pages 1-40 in "Women like this": New Perspectives on Jewish Women in the Greco-Roman World. Edited by AJ Levine. Atlanta: Scholars Press.

Charlesworth, JH 1985. The Old Testament Pseudepigrapha. Vol. 2. New York: Doubleday.

Christ, C and Plaskow, J (eds.) 1979. Womanspirit Rising: A Feminist Reader in Religion. San Francisco: Harper \&Row.

Clark, EA 1983. Women in the Early Church. Wilmington: Michael Glazier.

De Jonge, M and Tromp, J 1997. The Life of Adam and Eve and Related Literature. Sheffield: Sheffield Academic Press.

Di Lella, AA 1987. The Wisdom of Ben Sira. New York: Doubleday.

Fontaine, CR 1997. The Abusive Bible: On the Use of Feminist Method in Pastoral Contexts. Pages 84-113 in A Feminist Companion to Reading the Bible: Approaches, Methods and Strategies. Edited by A. Brenner and C. Fontaine. Sheffield: Sheffield Academic Press.

Hampson, MD 2002. After Christianity. London: SCM Press.

Higgins, JM 1976. The Myth of Eve: The Temptress. Journal of the American Academy of Religion 44:639-647. 
Jacobs, MM 2002. Vroue en die Nuwe Hervorming: Afskeid van die Pastoor. Bladsye $112-$ 133 in Die Nuwe Hervorming. Geredigeer deur P. Müller. Pretoria: Protea Boekhuis.

Köstenberger, AJ, Schreiner, TR and Baldwin, HS 1995. Women in the Church: A Fresh Analysis of 1 Timothy 2:9-15. Grand Rapids: Baker Books.

Milne, PJ 1999. Labouring with Abusive Biblical Texts: Tracing Trajectories of Misogyny. Pages 267-282 in The Labour of Reading: Desire, Alienation and Biblical Interpretation. Edited by FC Black, R Boer and E Runions. Atlanta: Scholars Press.

Mostert, B 2003. Verander jou Wêreld deur Gebed. Vanderbijlpark: Carpe Diem.

Norris, P 1999. The Story of Eve. London: Papermac.

Pagels, E 1988. Adam, Eve and the Serpent. New York: Random House.

Phillips, JA 1984. Eve: The History of an Idea. San Francisco: Harper \& Row.

SawyeR, DF 1996. Women and Religion in the First Christian Centuries. London: Routledge.

---- 1992. A Walk in the Garden: Biblical, Iconographical and Literary Images of Eden. Sheffield: JSOT Press.

Scholer, DM 2003. 1 Timothy 2:9-15 and the Place of Women in the Church's Ministry. Pages 98-121 in A Feminist Companion to the Deutero-Pauline Epistles. Edited by AJ Levine. New York: Continuum.

Schüngel-Straumann, H 1993. On the Creation of Man and Woman in Genesis 1-3: The History and Reception of the Text Considered. Pages 53-76 in A Feminist Companion to Genesis. Edited by A Brenner. Sheffield: Sheffield Academic Press.

Trible, P 1979. Eve and Adam: Genesis 2-3 Reread. Pages 74-83 in Womanspirit Rising: A Feminist Reader in Religion. Edited by C. Christ and J. Plaskow. San Francisco: Harper \& Row.

Van Wolde, E 1989. A Semiotic Analysis of Genesis 2-3: A Semiotic Theory and Method of Analysis Applied to the Story of the Garden of Eden. Assen: Van Gorcum. 